Military Technical College

Kobry El-Kobbah,

Cairo, Egypt

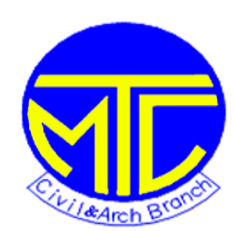

$12^{\text {th }}$ International Conference

on Civil and Architecture

Engineering

ICCAE-12-2018

\title{
Effect of spatial resolution on runoff volume and sediment yield
}

Gamal M. El Sheaky*, Osama M. Moussa**, Ahmed M. El Desoky**, Hosam M El Hanafy**

*Civil Engineering Department, Ph D Candidate M T C.

** M. T. C., Egypt

\begin{abstract}
Raster-based Digital Elevation Models (DEM) is recently used for representing elevation surface in watershed modeling. As different resolution of elevation models could be available, this study investigates the impact of DEM resolution on volume of runoff and sediment yield for different rainfall events of the Bagoush watershed in northern coast of Egypt about $50 \mathrm{~km}$ east of Matrouh city. The Digital Elevation Model with spatial resolution of $30 \mathrm{~m}$ and $12 \mathrm{~m}$ were used for comparative examinations. By using GIS (Geographic Information System) software Arc-Hydro, a 30m and 12m DEM's resolution are created to delineate the watershed and extracted the drainage pattern. The overall stream slopes and lengths are measured. The measured watershed parameters are used as input data for WASHMO model in order to get water inflow and sediment discharge also to generate runoff hydrograph and sedimentgraph. The results are compared with the aerial photo results which are considered as a basis of such work.
\end{abstract}

The results of this study showed that DEM's resolutions affects the watershed delineation, moreover the study showed that the volume of runoff for $12 \mathrm{~m}$ and $30 \mathrm{~m}$ DEM resolutions are differ than that aerial photo by approximately $31 \%$ and $39 \%$, respectively. While for the sediment yield for 
$12 \mathrm{~m}$ and $30 \mathrm{~m}$ DEM resolution are differ by approximately $9 \%$ and $28 \%$ respectively for each rainfall events.

Keyword: Watersheds, Hydrological model, sediment yield, Air born, Space born.

\section{Introduction}

The effective control of floods requires implementation of the best management practices to predict the effective runoff and sediment yield. The use of GIS (Geographic Information System) gives the advantage to the researchers to identify and overcome the floods problems. Digital Elevation Models (DEM) offer an efficient way to represent ground surface and allow automated direct extraction of hydrological features, thus bringing advantages in terms of processing efficiency, cost effectiveness and accuracy assessment, compared with traditional methods based on topographic maps, field surveys or photographic interpretations. For the last few decades, DEMs are widely used for resource management, urban planning, transportation planning, earth sciences, environmental assessments and Geographic Information System (GIS) applications. The raster DEM is used as a base map layer to derive the topographic attributes of the watershed such as area, slope and field slope length. Resolution of elevation data represents the horizontal accuracy of a DEM. An issue with the topography based hydrologic modeling has been that at what spatial resolution a model would perform optimally. There are several studies to investigate the effect of using different resolution DEM on the results from hydrological and hydraulic modeling.

In 1994 Zhang and Montgomery[1] studied the effect of grid cell resolution on landscape representation and hydrologic simulations using elevation data from two small watersheds and found that increasing the grid size resulted in an increased mean topographic index because of increased contributing area and decreased slopes.

In 1996 Mamillapalli et al[2], reported that modeled results from the Soil and Water Assessment Tool (SWAT) showed increased accuracy while predicting discharge with a finer resolution of data, however, they also found an interesting result that there was a level (threshold) beyond which higher resolution of data does not produce better results of predicted flow. 


\begin{tabular}{|l|l|}
\hline WR & 1 \\
\hline
\end{tabular}

In 2000 FitzHugh and Mackay[3], using the Soil and Water Assessment Tool (SWAT), indicated in a watershed of Wisconsin a $44 \%$ drop of sediment estimates from the coarsest to the finest watershed delineations. A decrease of sediment yield was observed with an increase of DEM mesh from 100 to $200 \mathrm{~m}$ due to decreasing channel erosion.

In 2005 Chaplot[4], evaluated the impact of the mesh size of DEM (from 20 to 500 m) within SWAT to simulate runoff, sediment and $\mathrm{NO}_{3}-\mathrm{N}$ loads at the outlet of an agricultural watershed. This study showed that an upper limit to DEM mesh size of 50 $\mathrm{m}$ was required to simulate sediment and $\mathrm{NO}_{3}-\mathrm{N}$ loads.

The objective of this research is to study the effect of DEMs resolutions on the volume runoff and sediment yield.

\section{Study Area}

The northwestern coast of Egypt represents one of the highest-priority regions for future development. In general Egypt located in north of Africa continent and bounded by longitudes 24.700 to $36.900 \mathrm{E}$ and latitudes 21.720 to $31.670 \mathrm{~N}$ and covers with $995,450 \mathrm{~km}^{2}$ of the land and $6,000 \mathrm{~km}^{2}$ of water.

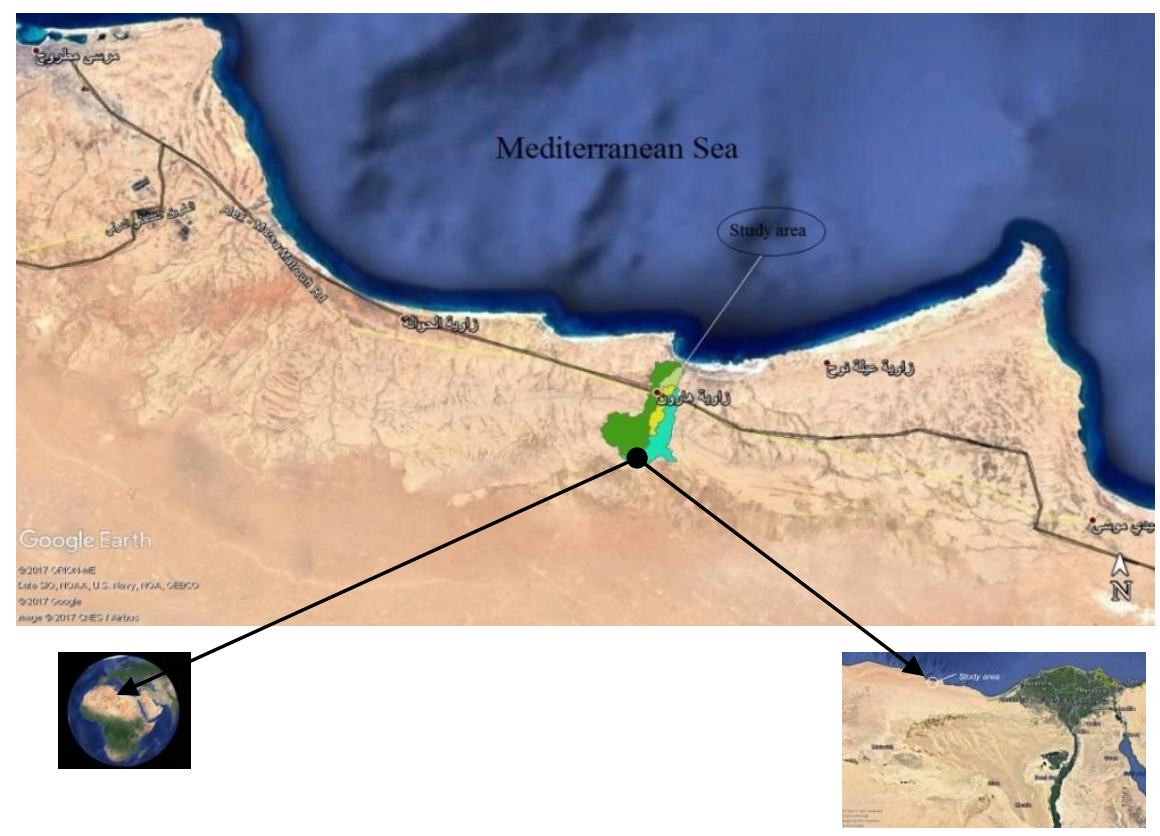

Figure (1) Location of the study area 
The watershed area covers an area about $17 \mathrm{~km}^{2}$ and its outlet station at $31^{\circ} 10^{\prime}$ $45^{\prime \prime} \mathrm{N}, 27^{\circ} 38^{\prime} 37^{\prime \prime} \mathrm{E}$. The watershed is located $51 \mathrm{~km}$ east of Marsa Matruh City and extend about $7 \mathrm{~km}$ south from the Mediterranean coast as shown in Figure (1).

\section{2-1 Topography of the Study Area}

The area of study comprises two different geomorphologic units; the coastal plain in north, where the landscape is characterized by the presence of alternating ridges and shallow depression, and the tableland in south which is dominated by innumerable deep consequent valleys, acting during rainy seasons as active drainage arteries. The coastal plain in the study area has an area about $6.650 \mathrm{~km}^{2}$ and displays characteristic features resulting of the simultaneous influence of climatic, geologic, and tectonic factors accompanied by fluctuation of the Mediterranean Sea (El Shazly and Shata 1971)[5]. These features developed into geomorphologic units of distinctive types and characteristics, which reveal effective deposition and erosion cycles that prevailed through different agents and processes. The tableland occupies the southwestern parts of the study area with an area about $10.408 \mathrm{~km}^{2}$ and characterized by the presence of a scarp. According to Shata (1957)[6], this scarp is presumably a fault representing a sharp line of demarcation between two contrasting morphological and ecological steps of the Libyan plateau (the tableland in the study area is a part of the huge Libyan plateau which extends along the northern coast of Africa). Figure (2) shows physiographic of the study area watershed. 


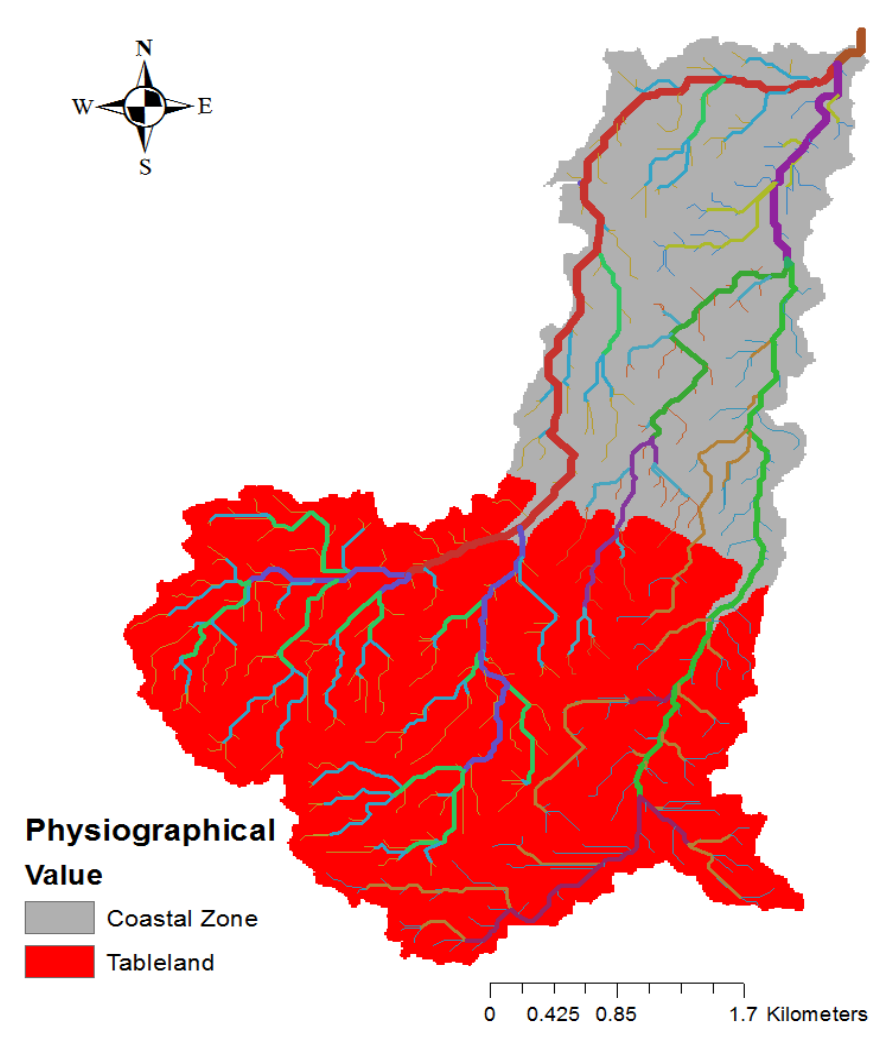

\section{Figure (2) Physiographic of the study area}

The elevation profile showing in Figure (4) started from outlet station at $31^{\circ} 10^{\prime} 45^{\prime \prime} \mathrm{N}, 27^{\circ} 38^{\prime} 37^{\prime \prime} \mathrm{E}$ to the remotest point in the drainage basin at station $31^{\circ} 7^{\prime} 13.903^{\prime \prime} \mathrm{N}, 27^{\circ} 36^{\prime} 39.809^{\prime \prime} \mathrm{E}$. The coastal zone of the study area characterized by different elevation above the sea level varies from (17 to $61 \mathrm{~m}$ ) and (61 to107 m) shaded grey and yellow in Figure (3), while the tableland zone is characterized by elevation varies from (107 to149 m) and (149 to178 $\mathrm{m})$ above the sea level and shaded with blue and red as shown in the Figure (3). 

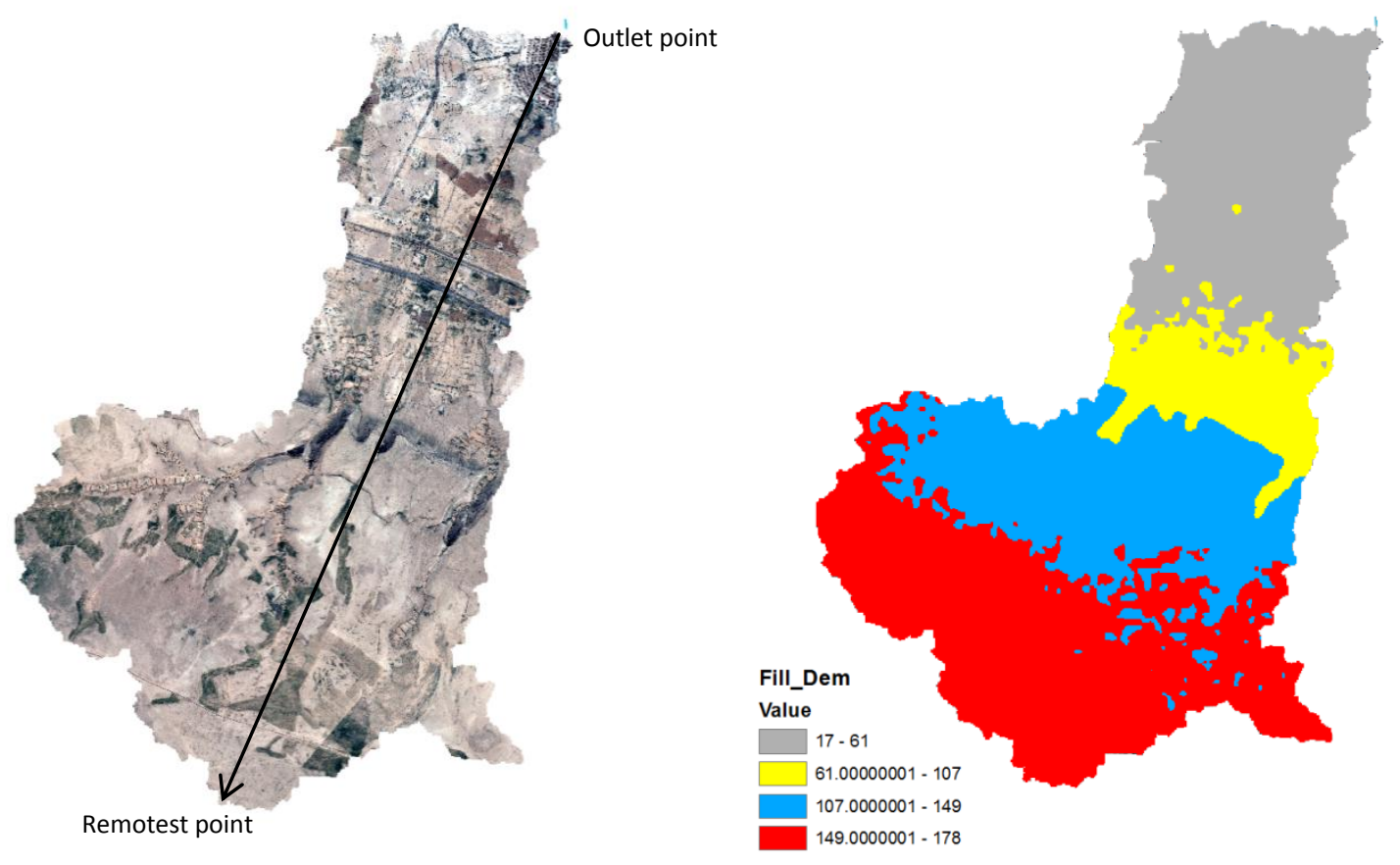

Figure (3) Topography and elevation of study area

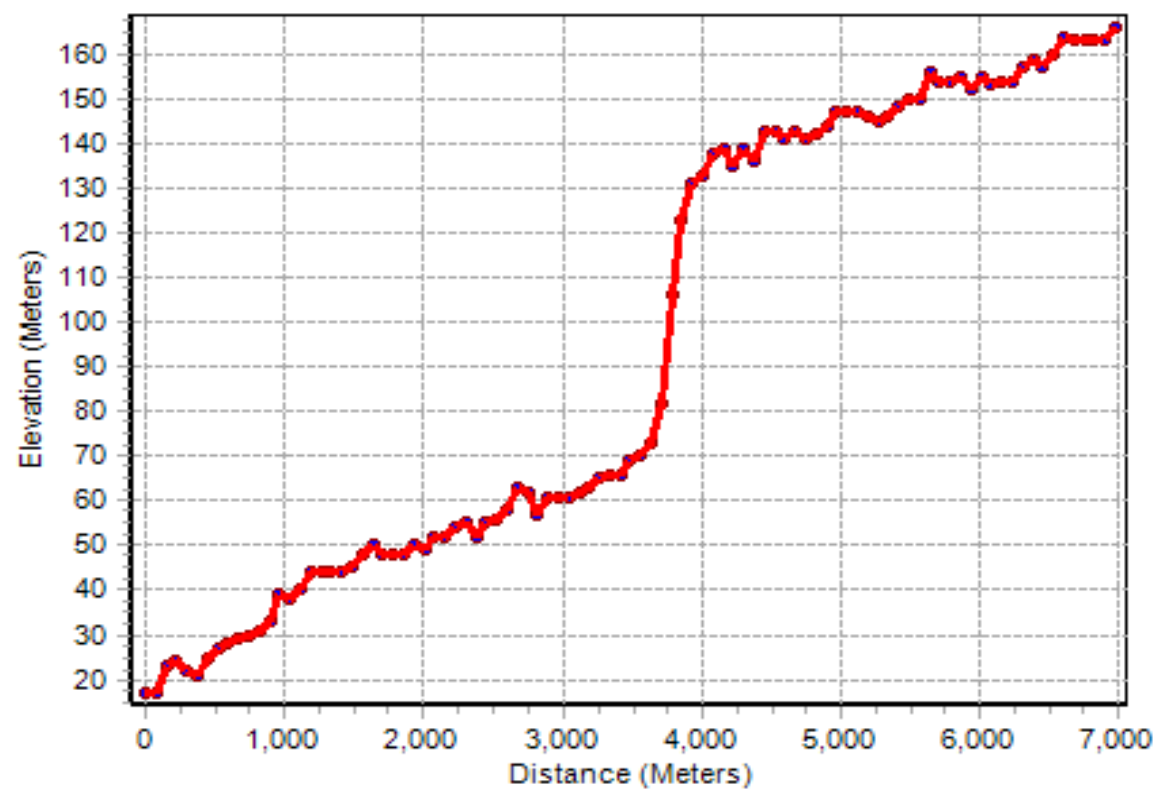

Figure (4) Elevation distance profile of watershed of study area 


\section{2-2 Geology of the Study Area}

Sedimentary rocks are of common occurrence, accounting for approximately $75 \%$ of the earth's exposed land surface. Sedimentary rocks are formed from sediment deposits when lithification or consolidation of loose materials into solid rock occurs. The drying process associated with exposure creates joints or cracks which are perpendicular to the original bedding planes and have no lateral movement. There are two categories of sedimentary rock. The first category includes rocks that are clastic or fragmental, such as shales, sandstones, and conglomerates. The second category includes sedimentary rocks formed from those chemical and organic sediments precipitated from solution. Rocks formed from these sediments include limestones, gypsum and salt. Sandstone deposits are resistant to the forces of weathering. Joint patterns, having the appearance of rectangular blocks, can be easily observed since there is little soil cover exists. The study area is considered as arid region. It is characterized by less than 20 inches of annual rainfall. In such arid region the land form are generally more rugged and without significant soil development over rock features.

\section{Model Description}

Watershed Storm Hydrograph-Multiple Option (WASHMO) model developed by Ward et al; 1979 consists of two models: one describing the hydrology of the watershed and the other describing the associated detachment and transport. The hydrology model mainly describes a design storm hydrograph. On the other hand, sediment yield in tons can be determined by using the modified version of the Universal Soil Loss Equation (USLE) developed by Hann and Barfield 1978[7].

\subsection{The hydrological model:}

The first model mainly describes a design storm hydrograph. It is capable of simulating the hydrological response of a watershed with only a 
limited amount of calibrated data. One of the most commonly used approaches to create such hydrograph is to use the well-known unit hydrograph procedures, as well as the soil conservation service curve number (SCS) method for estimating runoff.

The method was developed based on SCS procedure for small watersheds (SCS, 1973)[8]. Surface runoff is determined by equitation.

$$
Q=\frac{(P-A I)^{2}}{(P+S-A I)}
$$

Where: $\mathrm{Q}$ is the runoff in inches, $P$ is rainfall in inches; $\mathrm{AI}$ is the initial abstractions in inches, and $\mathrm{S}$ is defined as the potential maximum retention and determined as

$$
S=\frac{1000}{C N}-10
$$

Where: $\mathrm{CN}$ is the SCS curve number, the curve number is an indicator of the runoff potential of an area varies with soil type, land use, and soil moisture conditions.

\section{3-2 The sediment detachment and transport model}

The process by which soil particles are eroded contains three interrelated phenomena detachment, transport and sedimentation.

Detachment occurs when a soil particle is dislodged from the soil surface and/or from the aggregate to which it was attached.

Transport occurs once the detachment process takes place the bonding mechanisms are no longer effective in keeping individual particles in place. These particles will be easily transported by water, surface runoff, wind or gravity. 
Sedimentation is the tendency for particles in suspension to settle out of the fluid in which they are entrained and come to rest against a barrier. This is due to their motion through the fluid in response to the forces acting on them: these forces can be due to gravity, centrifugal acceleration, or electromagnetism.

The modified version of the Universal Soil Loss Equation as developed by Ward et al, 1979[9] will be in the form:

$$
Y_{S}=95\left(Q q_{p}\right)^{0.56} K L_{S} C P_{r}
$$

Where:

$Y_{S} \quad$ is the sediment yield from the storm (tons).

$Q \quad$ is the volume of runoff in (acre - feet).

$q_{p} \quad$ is the peak runoff rate $(c f s)$.

$K \quad$ is the soil erodibiity factor.

$\mathrm{L}_{\mathrm{S}} \quad$ is the slope - length factor.

C is the ground cover factor.

$P_{r} \quad$ is the reclamation practice factor.

\section{Data Acquisition}

This study describes the different datasets used for the experimental work, whether the data acquired from the general meteorological authority and field investigation or the data acquired from space.

\subsection{Global data}

The global parameters which includes Rainfall $(\mathrm{mm})$, storm duration (hours), initial abstraction (mm), time increment of hydrograph from start of run-off (hours), Rainfall distribution patterns, and the number of sub watersheds. 


\section{Rainfall}

Storms events characteristics with maximum rainfall amount and duration for the watershed which lies on the coastal region were acquired and studied to insert it into WASHMO model as an input data. Regarding to Meteorological rainfall data that have been recorded at Marsa Matruh station, by General Meteorological Authority, the significant rainfall amounts during the period from 1977 until 2003 was found to be $7 \mathrm{~mm}$ at SEP-2000, $8 \mathrm{~mm}$ at DEC-1989, $12 \mathrm{~mm}$ at Feb-2002, $13 \mathrm{~mm}$ at Feb-2003, $19 \mathrm{~mm}$ at DEC-1997, $60.4 \mathrm{~mm}$ at DEC-1977 and $103.5 \mathrm{~mm}$ at DEC-1991.

\section{Storm duration}

Hydrologists are much interested in the statistical characteristics of precipitation events. The two most important storm characteristics are duration and average precipitation intensity. The product of duration and average precipitation gives the total precipitation volume during the storm. Sutko and Syndi, (1990) recommended that the 24-hour design storm resulted in higher peak values discharges and larger volumes of runoff than shorter duration storms[10]. So the storm duration had chosen 24-hour for the four watersheds in the study area.

\section{Initial abstractions}

Abstractions from precipitation are losses from precipitation that do not show up as storm water runoff. Thus, the volume of storm water runoff will be the volume of precipitation minus abstractions. Abstractions include interception, evaporation, infiltration, surface storage, surface detention and bank storage. Initial abstractions include the interception and surface storage. The soil conservation service (SCS) had recommended this value to be taken as zero mm. (Ward et. al, 1979)[9].

Soil conservation service curve number $(\mathrm{CN})$ 
The SCS curve number method, also known as the Hydrologic Soil Cover Complex Method was developed by the Soil Conservation Service (SCS) of the U.S. Department of Agriculture for use in rural areas. It is a versatile and widely used procedure for runoff estimation. The requirements for this method are rainfall amount and curve number as mentioned in Equations (1 and 2 in section 3-1). The curve number is based on the areas hydrologic soil group, land use treatment and hydrologic condition. The SCS has classified more than 4000 soils into four groups (A, B, C and D), depend on infiltration, soil classification and other criteria as described in table (1). SCS-CN represents the runoff potential of an area for the watershed, by using Hann and Barfield, 1978 approaches, see Tables 1 and 2, SCS-CN was found to be 94.

\section{Table (1): Definition of SCS hydrologic soil groups}

\begin{tabular}{|c|c|}
\hline A & $\begin{array}{c}\text { These soils with a high infiltration rate. They are chiefly deep, well-drained } \\
\text { sands or gravels (Low runoff potential). }\end{array}$ \\
\hline B & $\begin{array}{c}\text { These soils with a moderate infiltration rate when thoroughly wet. They are } \\
\text { chiefly moderately deep, well drained soils of moderately fine to moderately } \\
\text { course texture. }\end{array}$ \\
\hline C & $\begin{array}{c}\text { These soils with a slow infiltration rate when wet. They are chiefly moderately } \\
\text { deep, well drained soils of moderately fine to moderately course texture. }\end{array}$ \\
\hline D & $\begin{array}{c}\text { These soils with a very slow infiltration rate. They are chiefly clay soils with a } \\
\text { high swelling potential, soils with a permanently high water table, soils with a } \\
\text { clay pan at or near the surface and shallow soils over nearly impervious } \\
\text { materials (High runoff potential). }\end{array}$ \\
\hline
\end{tabular}


Table (2): Runoff curve number for selected agriculture (Antecedent Moisture Conditions II)

\begin{tabular}{|c|c|c|c|c|}
\hline \multirow{2}{*}{ Land use description } & \multicolumn{4}{|c|}{ Hydrological soil group } \\
\cline { 2 - 5 } & A & B & C & D \\
\hline Commercial, raw houses and townhouses & 80 & 85 & 90 & 95 \\
\hline Fallow, poor condition & 77 & 86 & 91 & 94 \\
\hline Cultivated with conventional tillage & 72 & 81 & 88 & 91 \\
\hline Cultivated with conservation tillage & 62 & 71 & 78 & 81 \\
\hline Lawns, poor condition & 58 & 74 & 82 & 86 \\
\hline Lawns, good condition & 39 & 61 & 74 & 80 \\
\hline Pasture or range, poor condition & 68 & 79 & 86 & 89 \\
\hline Pasture or range, good condition & 39 & 61 & 74 & 80 \\
\hline Meadow & 30 & 58 & 71 & 78 \\
\hline Pavement and roofs & 100 & 100 & 100 & 100 \\
\hline Woods or forest thin stand, poor cover & 45 & 66 & 77 & 83 \\
\hline Woods or forest, good cover & 25 & 55 & 70 & 77 \\
\hline Farmsteads & 59 & 74 & 82 & 86 \\
\hline
\end{tabular}

\section{Rainfall distribution}

Currently, Natural Resources Conservation Service (NRCS) uses standard synthetic 24-hour rainfall distributions identified as Type I, Type IA, Type II and Type III. These distributions are used for evaluation studies (Flood Insurance Studies, Flood Plain Management studies, flood routings, urban damage evaluations, etc.) as related to evaluation of 24-hour events (i.e. 1-year generally up through 500-year events). 


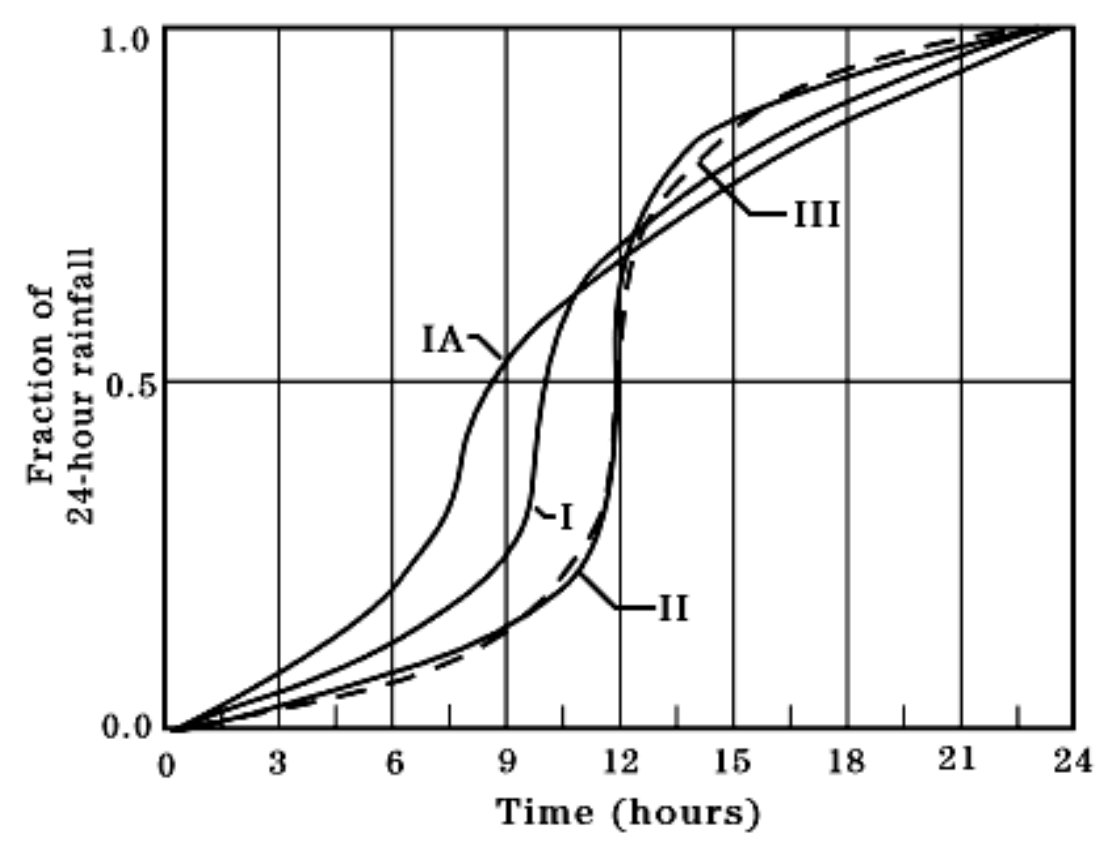

Figure ( 5 ): NRCS 24-hour rainfall distributions[11]

The model used in this study (WASHMO) is written to allow its user the choice of two standard synthetic rainfall patterns (SCS type 1. and SCS type 2) or the option of inputting a pattern of his choice. So, in this research the SCS type 2 curve is used as an input rainfall distribution to result in maximum runoff.

\subsection{Space data}

A $30 \mathrm{~m}$ resolution of Digital Elevation Model (DEM) provided by Shuttle Radar Topography Mission (STRM) and $12 \mathrm{~m}$ resolution DEM provided by Advanced Land Observing Satellite (ALOS). The ALOS satellite was launched on January 24, 2006. ALOS had a 46-day repeat cycle and operated until May 12, 2011.

\subsection{Map data}

Which includes the area (ha.), hydraulic length (m.), percentage of forest $(\%)$, percentage of agriculture (\%), percentage of grassland (\%), overland flow 
slope (\%), channel slope (\%), channel length from subwatershed (m.), and type of the channel from subwatershed. The above parameters are acquired and recognized from different sources which are, the map data acquired from satellite and the map data acquired from aerial photographs.

\subsubsection{The map data acquired from satellite}

By using different resolutions (12m and 30m ) Digital Elevation Model with ARC.GIS10.3 and arc-hydro software the drainage pattern for $12 \mathrm{~m}$ and $30 \mathrm{~m}$ DEMs are extracted as showing in figure (6) and the map parameters are measured and listed in Table ( 3 and 4 ).

Table (3) The map parameters for $12 \mathrm{~m}$ DEM resolution

\begin{tabular}{|c|c|c|c|c|}
\hline Map Parameters & Sub-1 & Sub-2 & Sub-3 & Sub-4 \\
\hline Area (ha) & 484.89 & 187.89 & 879.843 & 107.421 \\
\hline Hydraulic Length (m) & 7417.3 & 4101.91 & 8972.12 & 2733.78 \\
\hline Channel slope \% & 1.77 & 2.52 & 1.71 & 1.43 \\
\hline Overland flow slope \% & 1.6 & 3.11 & 1.89 & 4.23 \\
\hline Overland flow length (m) & 170.83 & 141.28 & 158.76 & 140.35 \\
\hline Length from subwater (m) & 2090.54 & 2095.52 & 352.69 & 0 \\
\hline Agric. (\%) & 7.04 & 6.14 & 6.02 & 0.85 \\
\hline Forest (\%) & 0 & 0 & 0 & 0 \\
\hline Grass (\%) & 0.1 & 0.1 & 0.1 & 0.1 \\
\hline
\end{tabular}

Table ( 4 ) The map parameters for $30 \mathrm{~m}$ DEM resolution

\begin{tabular}{|c|c|c|c|c|}
\hline Map Parameters & Sub-1 & Sub-2 & Sub-3 & Sub-4 \\
\hline Area (ha) & 618.88 & 73.21 & 925.55 & 147.69 \\
\hline Hydraulic Length (m) & 6314.51 & 1690.2 & 8574.26 & 2364.76 \\
\hline Channel slope \% & 1.93 & 0.797 & 1.76 & 1.46 \\
\hline Overland flow slope \% & 2.88 & 0.937 & 1.43 & 3.12 \\
\hline Overland flow length (m) & 370.2 & 75.92 & 401.91 & 306.68 \\
\hline Length from subwater (m) & 1907.55 & 1907.55 & 382.55 & 0 \\
\hline Agric. (\%) & 8.98 & 2.39 & 6.12 & 1.1 \\
\hline Forest (\%) & 0 & 0 & 0 & 0 \\
\hline Grass (\%) & 0.1 & 0.1 & 0.1 & 0.1 \\
\hline
\end{tabular}




\begin{tabular}{|l|l|}
\hline WR & 1 \\
\hline
\end{tabular}

30 m Resolution

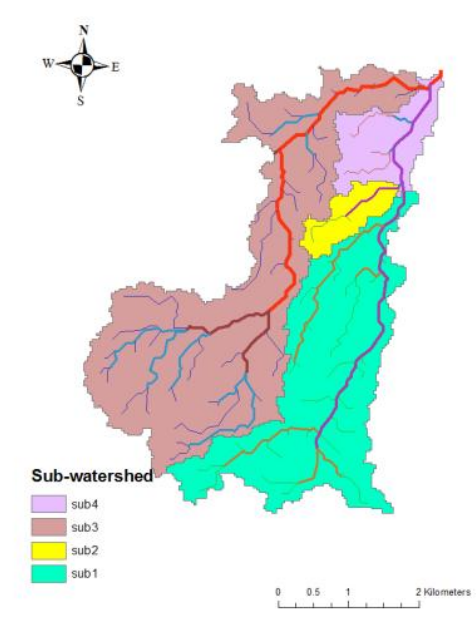

12 m Resolution

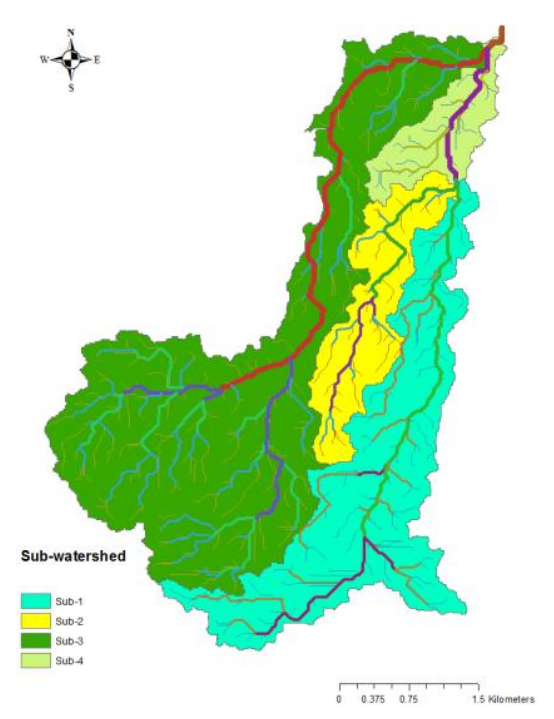

Figure (6): Drainage pattern for $12 \mathrm{~m}$ and 30m DEM

\subsubsection{The map data acquired from aerial photographs}

Aerial photographs scale 1:40,000 and topographic maps scale 1:50,000 and 1:25,000 are used to measure the map parameters as shown in Figure (7). Table (5) shows the map parameters collected from aerial photograph.

Table ( 5 ): The map parameters for aerial photographs

\begin{tabular}{|c|c|c|c|c|}
\hline Map Parameters & Sub-1 & Sub-2 & Sub-3 & Sub-4 \\
\hline Area (ha) & 272.43 & 261.34 & 620.93 & 108.43 \\
\hline Hydraulic Length (m) & 4846.48 & 5061.83 & 6050.82 & 1632.41 \\
\hline Channel slope \% & 2.23 & 2.23 & 1.9 & 1.65 \\
\hline Overland flow slope \% & 2.86 & 1.84 & 2.1 & 1.32 \\
\hline Overland flow length (m) & 885.05 & 921.6 & 940.69 & 484.85 \\
\hline Length from subwater (m) & 1473 & 1473 & 1342 & 390 \\
\hline Agric. (\%) & 2.84 & 8.54 & 4.12 & 2.73 \\
\hline Forest (\%) & 0 & 0 & 0 & 0 \\
\hline Grass (\%) & 0.1 & 0.1 & 0.1 & 0.1 \\
\hline
\end{tabular}




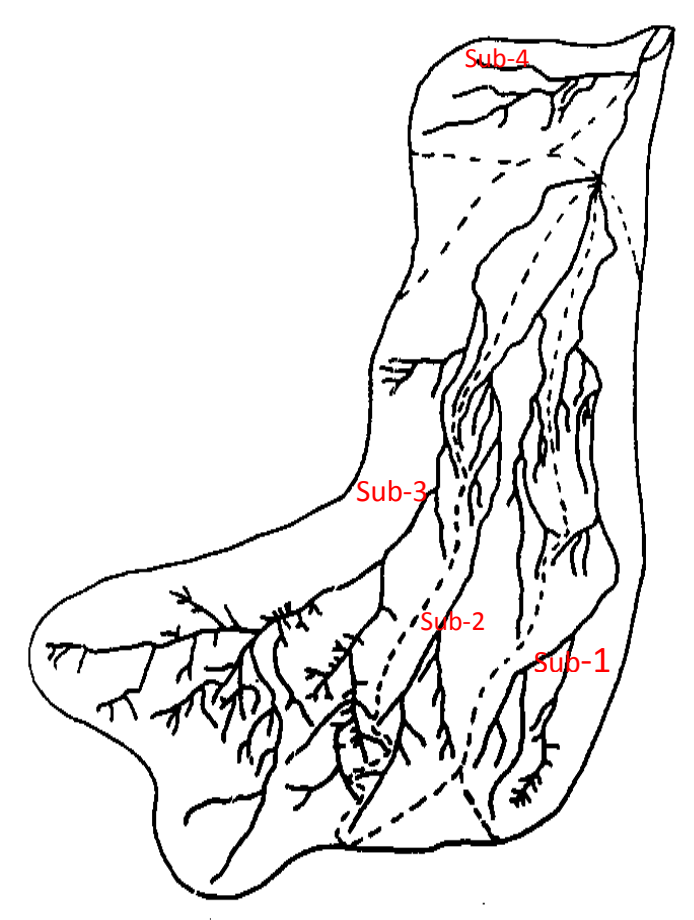

Figure (7): Drainage pattern from aerial photo

\subsection{Sediment data}

The value of soil erodibility factor( $\mathrm{K}$ ) varies from a specific kind of soil to another according to the different properties of soil itself. Silt fraction content, percent of sand in soil, soil structure, organic matter content and permeability class are the most common properties that have been used to determine such factor either from empirical equations, tables or from soil erodibility nomographs. From nomograph, $\mathrm{K}$ was determined and found to be 0.14 (Wischmeier and Smith,1978)[12].

\section{Results and analysis}

This section presents the study area collected data processing and the results at 1991. The processing of data includes two main categories: Drainage pattern extraction based on aerial photography with aid of topographic map with scale 
1:250,000, Drainage pattern extraction based on Digital Elevation Model data processing with two different resolution (30m and $12 \mathrm{~m})$.

\subsection{Results based on aerial photography}

The photo interpretation of the aerial photo of the study area at 1991 scale (1:40000) with aid of mirrors stereoscope device and stereo plotters were conducted. The drainage pattern for the area of interest is extracted and divided to four sub watershed, each sub watershed has main hydraulic length and drainage point also by using of Planix-5000 digitizing area-line meter, electronic digitizer the area of each sub watersheds, lengths of main streams and overland flow lengths were measured. On the other hand the topographic maps scale (1:25000) at 1991 that been established by the military survey administration are used to determine slopes of the main streams and mean slopes for overland lengths. All these parameters are tableted in Table (5) and used as input data for WASHNO model. The WASHNO model consists of two models: one describing the hydrology of the watershed and the other describing the associated detachment and transport, the results of each model are illustrated in and Table (6 and 7), on the other hand the storm hydrograph and storm sedimentgraph are plotted as shown in Figure (8 and 9).

Table (6) Result of storm hydrograph generated from start of rainfall using Arial photo 1991watershed.

\begin{tabular}{|c|c|c||c|c||}
\hline Results & $\begin{array}{c}\text { Volume of runoff } X \\
1000 \mathrm{~m}^{3}\end{array}$ & $\begin{array}{c}\text { Peak runoff rate } \\
\mathrm{m}^{3} / \mathrm{sec}\end{array}$ & $\begin{array}{c}\text { Time to peak runoff } \\
\text { rate }(\mathrm{hr})\end{array}$ & $\begin{array}{c}\text { Depth of water } \\
(\mathrm{mm})\end{array}$ \\
\hline Sub1 & 273.97 & 19.91 & 12.7 & 87.37 \\
\hline \hline Sub2 & 228.38 & 15.28 & 13.0 & 87.43 \\
\hline \hline Sub3 & 542.30 & 34.54 & 13.1 & 87.37 \\
\hline \hline
\end{tabular}




\begin{tabular}{|c|c|c|c|c|}
\hline $\begin{array}{c}\text { Entire } \\
\text { watershed }\end{array}$ & 1103.21 & 70.55 & 13.4 & 87.38 \\
\hline
\end{tabular}

Table (7) Result of storm sedimentgraph generated from start of rainfall using Arial photo 1991watershed.

\begin{tabular}{|c|c|c|c||}
\hline Results & $\begin{array}{c}\text { Sediment yield } \\
\text { (tones) }\end{array}$ & $\begin{array}{c}\text { Peak sediment concentration } \\
(\mathrm{mg} / \mathrm{l})\end{array}$ & $\begin{array}{c}\text { Time to peak sediment } \\
\text { concentration (hr) }\end{array}$ \\
\hline \hline Sub1 & 3839.72 & 35.88 & 12.7 \\
\hline \hline Sub2 & 2252.48 & 15.23 & 13.0 \\
\hline \hline Sub3 & 6436.02 & 16.28 & 12.3 \\
\hline \hline Sub4 & 812.19 & 43.93 & 12.60 \\
\hline \hline Entire & 13340.41 & 21.28 & \\
\hline
\end{tabular}

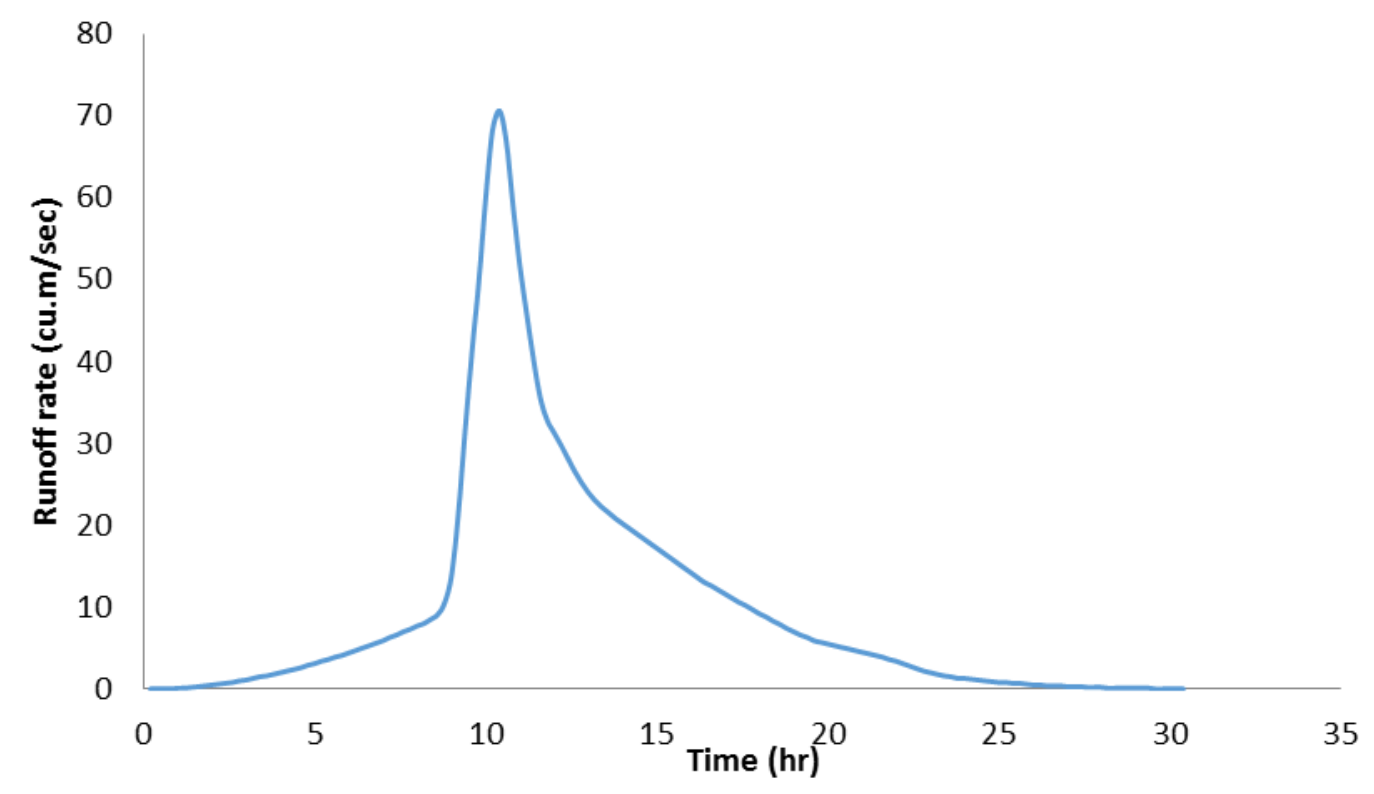




\section{Figure (8): Storm hydrograph for entire watershed, 1991}

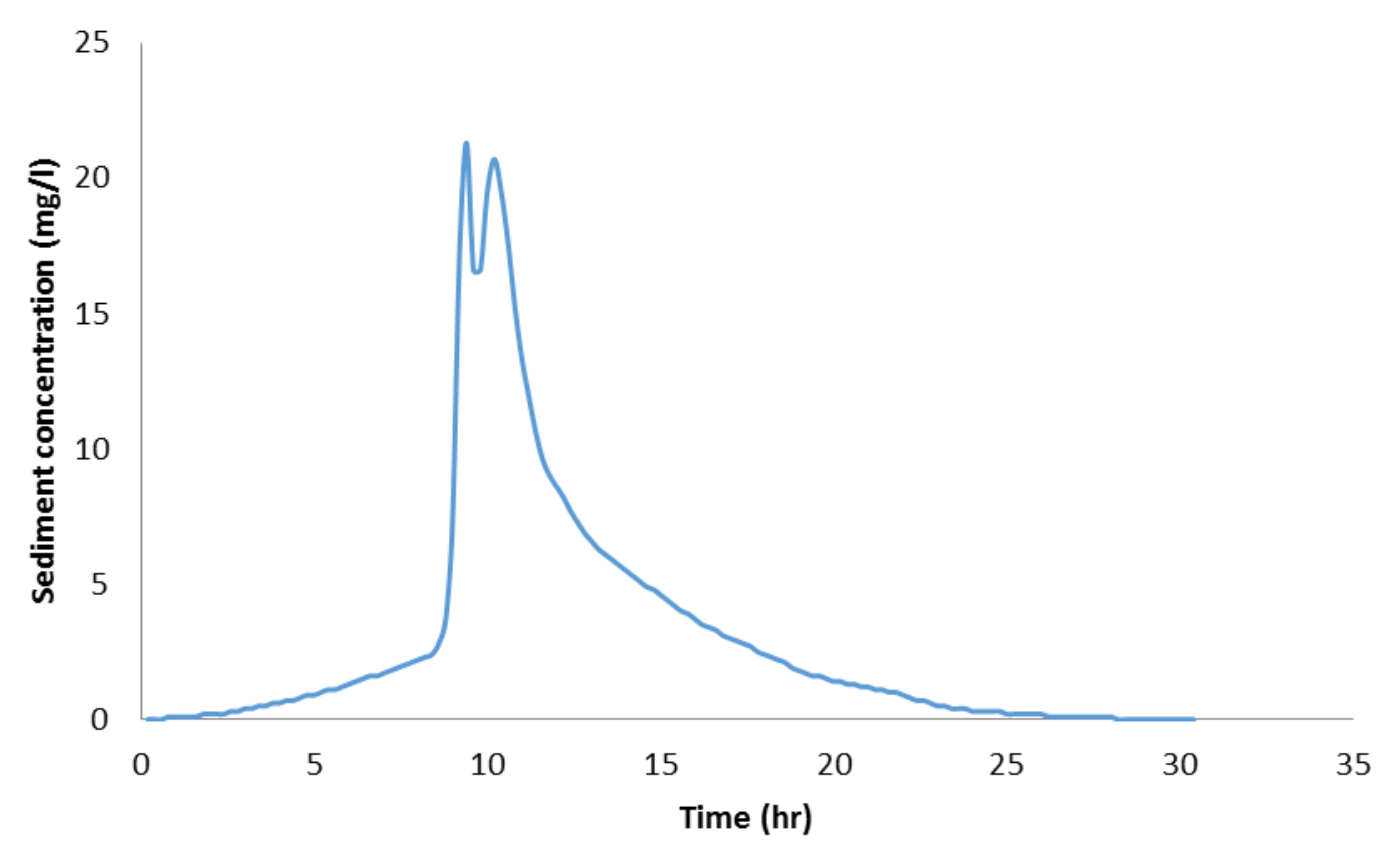

Figure (9): Storm sedimentgraph for entire watershed, 1991

\subsection{Analysis and results based on satellite (DEM)}

In this study will perform drainage analysis on a terrain model by using The Arc Hydro software to derive several data sets that collectively describe the drainage patterns of a catchment. Raster analysis is performed to generate data on flow direction, flow accumulation, stream definition, stream segmentation, and watershed delineation. These data are then used to develop a vector representation of catchments and drainage lines. Using this information, a geometric network is constructed. Utility of Arc Hydro tools is demonstrated by applying them to develop attributes that can be useful in hydrologic modeling. The generated data is illustrated in Figure (10) to Figure (16) for $30 \mathrm{~m}$ and $12 \mathrm{~m}$ DEM resolutions. 
30m Resolution

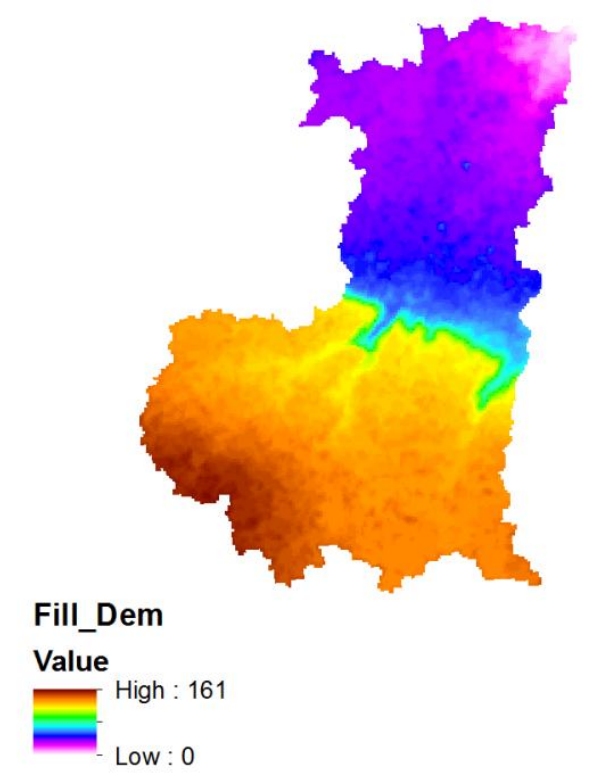

$12 \mathrm{~m}$ Resolution

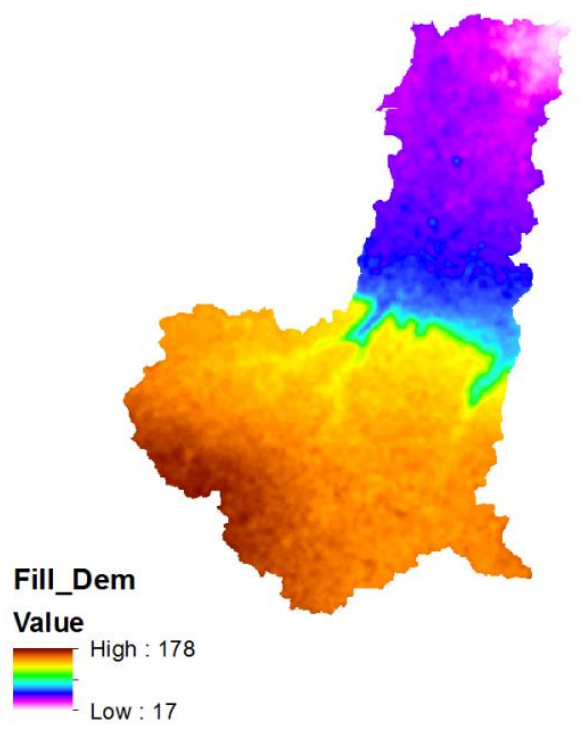

Figure (10) Filled DEM of the study area 1991

30m Resolution

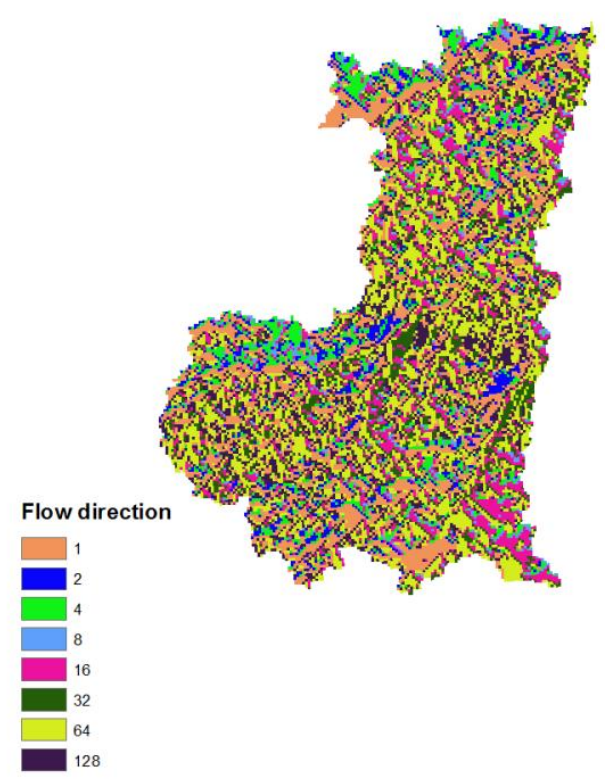

$12 \mathrm{~m}$ Resolution

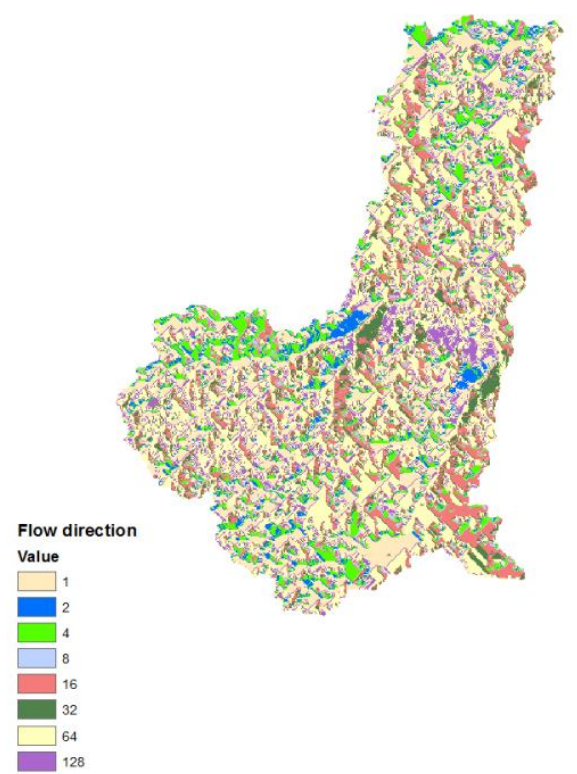

Figure (11) Flow direction of the study area 1991 
30m Resolution

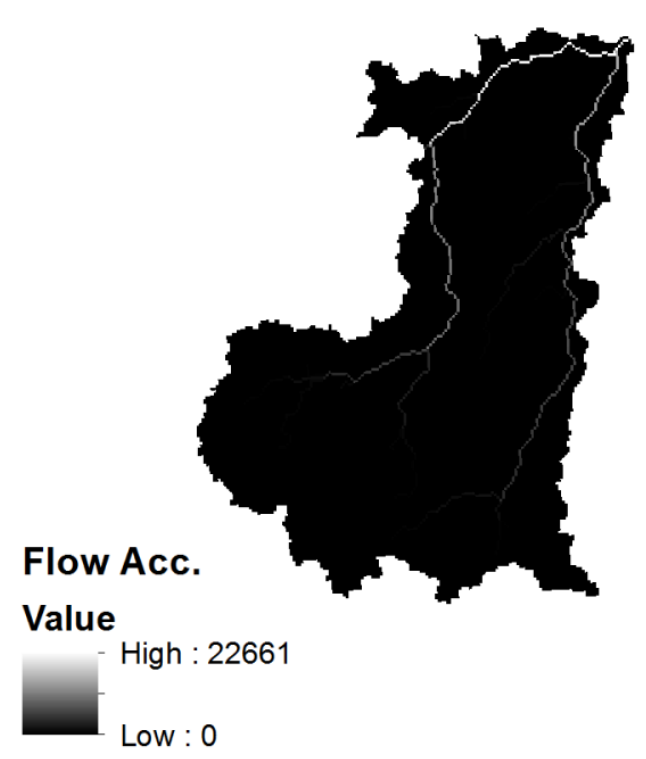

12m Resolution

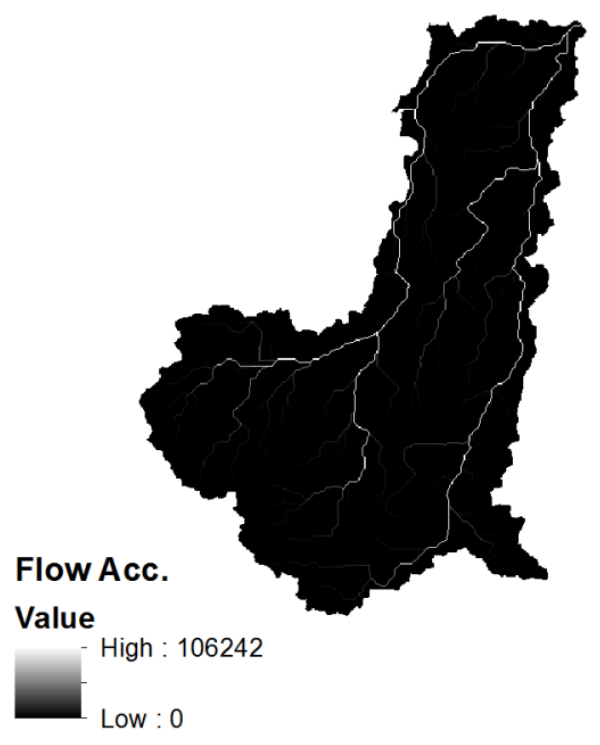

Figure (12) Flow accumulation of the study area

30m Resolution

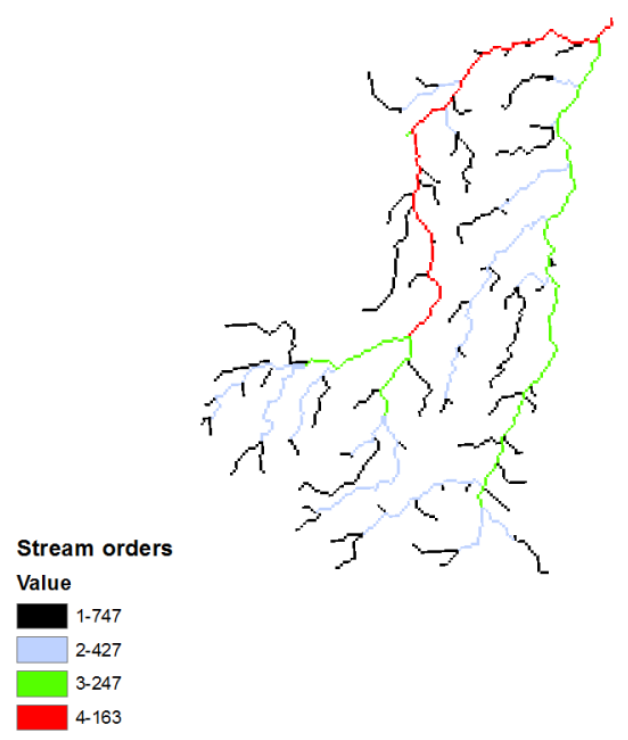

$12 \mathrm{~m}$ Resolution

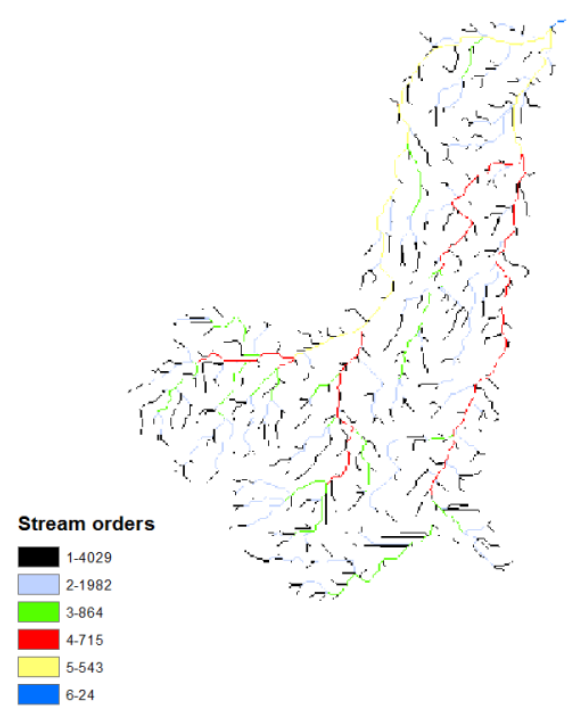

Figure (13) Strahler ordering system of study area 
30m Resolution

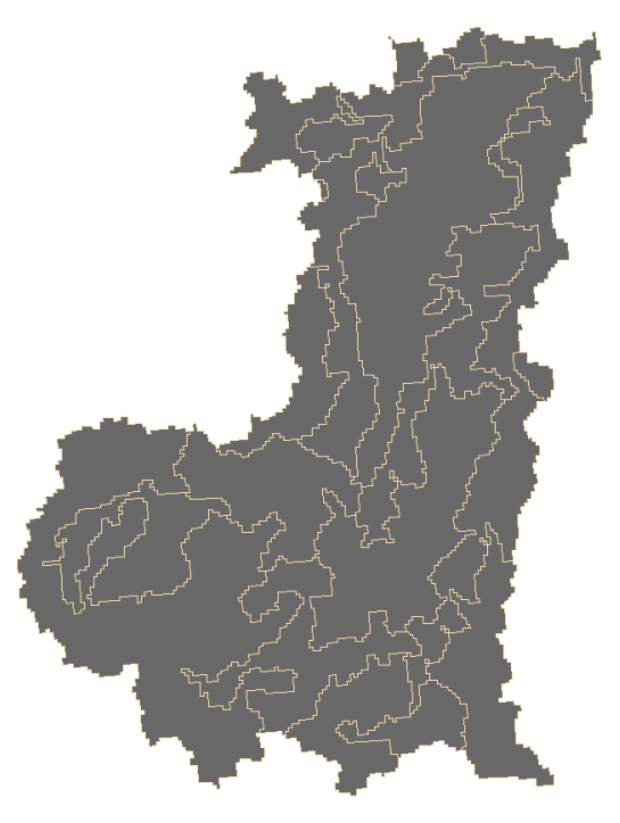

$12 \mathrm{~m}$ Resolution

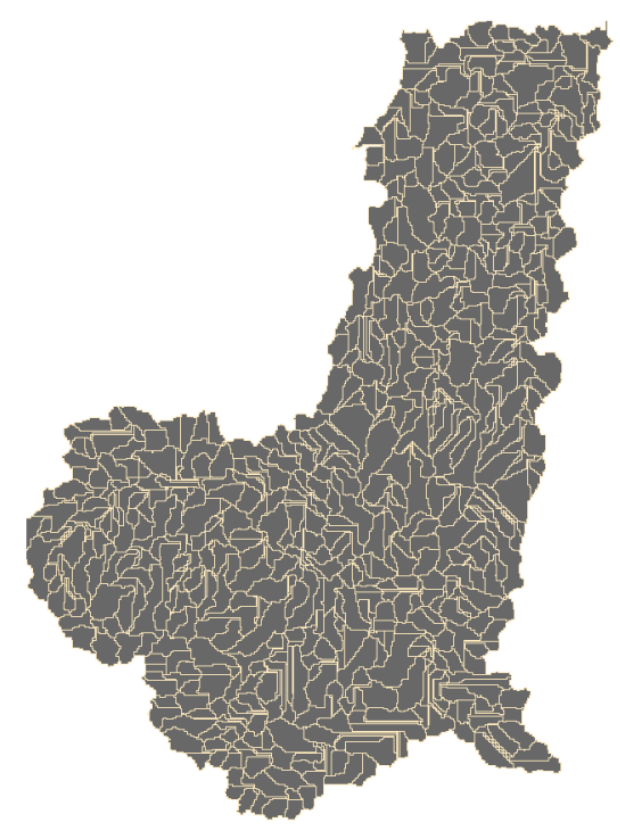

Figure (14) Catchment Polygon Processing

30m Resolution

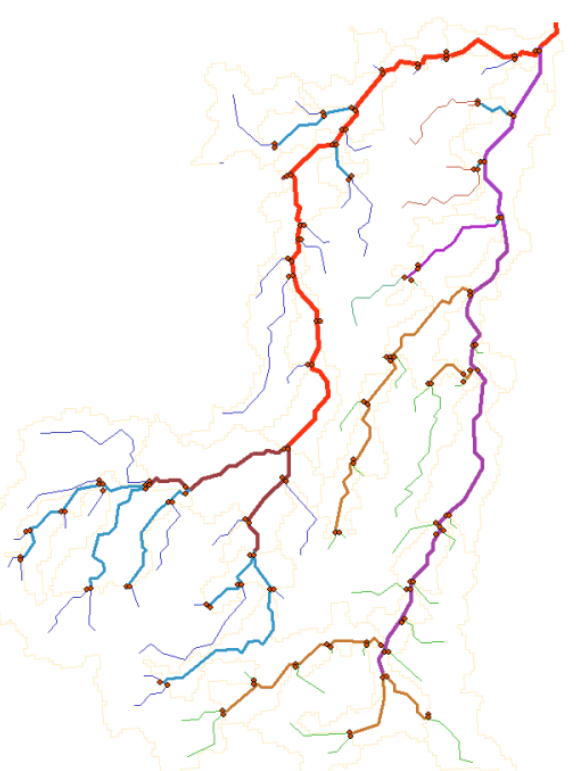

$12 \mathrm{~m}$ Resolution

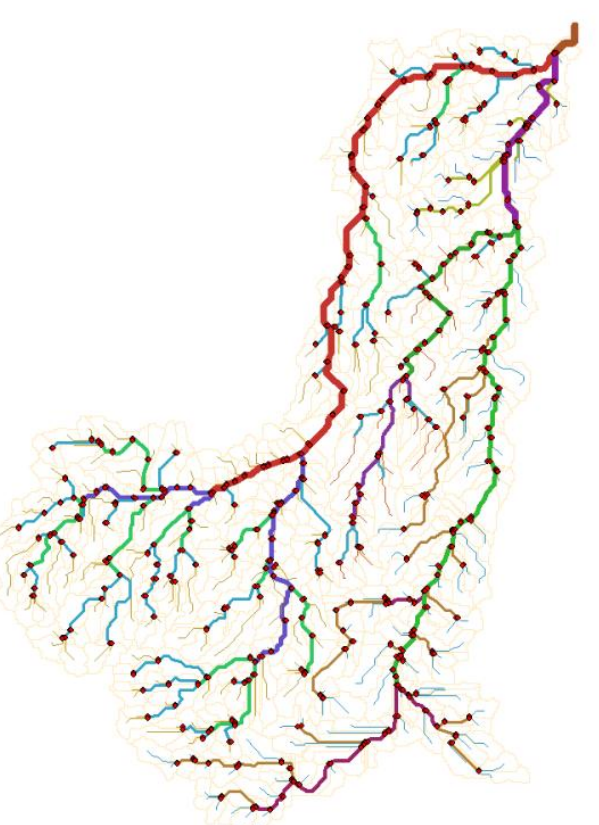

Figure (15) Drainage Point Processing 

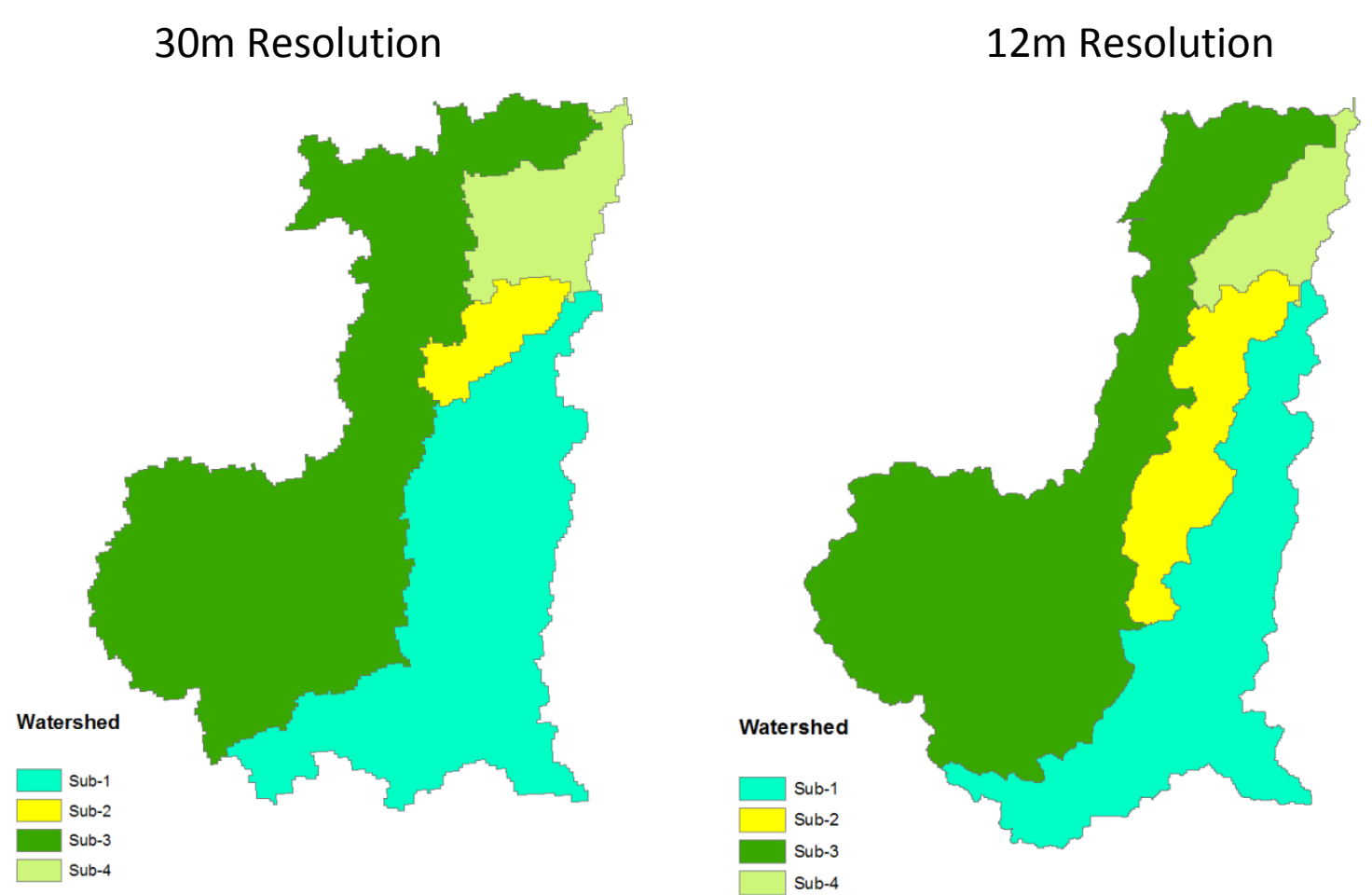

Figure (16) Basins and Sub-Basins of study area 
The Result of storm hydrograph and sedimentgraph generated from start of rainfall by 30m DEM resolution, 1991watershed are illustrated in Tables (8 and 9).

Table (8) Result of storm hydrograph for 30m DEM resolution

\begin{tabular}{|c||c|c||c|c||}
\hline \hline Results & $\begin{array}{c}\text { Volume of runoff } \\
\text { X } 1000 \mathrm{~m}^{3}\end{array}$ & $\begin{array}{c}\text { Peak runoff } \\
\text { rate } \mathrm{m}^{3} / \mathrm{sec}\end{array}$ & $\begin{array}{c}\text { Time to peak } \\
\text { runoff rate }(\mathrm{hr})\end{array}$ & $\begin{array}{c}\text { Depth of } \\
\text { water }(\mathrm{mm})\end{array}$ \\
\hline \hline Sub1 & 540.50 & 36.12 & 13.00 & 87.37 \\
\hline \hline Sub2 & 63.97 & 7.36 & 12.35 & 87.42 \\
\hline \hline Sub3 & 808.35 & 36.03 & 13.85 & 87.37 \\
\hline \hline Sub4 & 128.97 & 17.39 & 12.25 & 87.36 \\
\hline \hline $\begin{array}{c}\text { Entire } \\
\text { watershed }\end{array}$ & 1541.67 & 79.44 & 13.60 & 87.37 \\
\hline
\end{tabular}

Table (9) Result of storm sedimentgraph for 30m DEM resolution

\begin{tabular}{|c|c|c|c||}
\hline Results & $\begin{array}{c}\text { Sediment } \\
\text { yield (tones) }\end{array}$ & $\begin{array}{c}\text { Peak sediment } \\
\text { concentration }(\mathrm{mg} / \mathrm{l})\end{array}$ & $\begin{array}{c}\text { Time to peak sediment } \\
\text { concentration }(\mathrm{hr})\end{array}$ \\
\hline \hline Sub1 & 6576.15 & 18.76 & 13.00 \\
\hline \hline Sub2 & 229.69 & 14.15 & 12.35 \\
\hline \hline Sub3 & 5279.97 & 5.27 & 13.85 \\
\hline \hline Sub4 & 2000.0 & 80.63 & 12.40 \\
\hline Entire watershed & 14085.80 & 43.34 & 12.25 \\
\hline
\end{tabular}




\begin{tabular}{|l|l|}
\hline WR & 1 \\
\hline
\end{tabular}

The Result of storm hydrograph and sedimentgraph generated from start of rainfall by $12 \mathrm{~m}$ DEM resolution, 1991watershed are illustrated in Tables (10 and 11).

Table (10) Result of storm hydrograph for $12 \mathrm{~m}$ DEM resolution.

\begin{tabular}{|c||c||c|c|c||}
\hline \hline Results & $\begin{array}{c}\text { Volume of runoff } X \\
1000 \mathrm{~m}^{3}\end{array}$ & $\begin{array}{c}\text { Peak runoff } \\
\text { rate } \mathrm{m}^{3} / \mathrm{sec}\end{array}$ & $\begin{array}{c}\text { Time to peak } \\
\text { runoff rate (hr) }\end{array}$ & $\begin{array}{c}\text { Depth of } \\
\text { water (mm) }\end{array}$ \\
\hline \hline Sub1 & 423.49 & 20.70 & 13.60 & 87.37 \\
\hline \hline Sub2 & 164.19 & 15.51 & 12.55 & 87.42 \\
\hline \hline Sub3 & 768.43 & 35.03 & 13.80 & 87.37 \\
\hline \hline $\begin{array}{c}\text { Sub4 } \\
\text { Entire }\end{array}$ & 93.81 & 12.76 & 12.25 & 87.37 \\
\hline \hline
\end{tabular}

Table (11) Result of storm sedimentgraph for 12m DEM resolution.

\begin{tabular}{|c|c||c||c||}
\hline Results & $\begin{array}{c}\text { Sediment yield } \\
\text { (tones) }\end{array}$ & $\begin{array}{c}\text { Peak sediment } \\
\text { concentration (mg/l) }\end{array}$ & $\begin{array}{c}\text { Time to peak sediment } \\
\text { concentration (hr) }\end{array}$ \\
\hline \hline Sub1 & 2058.70 & 4.53 & 13.60 \\
\hline Sub2 & 1696.47 & 28.22 & 12.55 \\
\hline Sub3 & 4257.54 & 4.62 & 13.80 \\
\hline \hline Sub4 & 1539.00 & 86.30 & 12.45 \\
\hline \hline $\begin{array}{c}\text { Entire } \\
\text { watershed }\end{array}$ & 9551.70 & 40.78 & \\
\hline \hline
\end{tabular}


Table (12) Results comparison for aerial photo and satelite for different rainfall events

\begin{tabular}{|c|c|c|c|c|}
\hline \multirow{2}{*}{$\begin{array}{c}\text { Rainfall } \\
\text { events }\end{array}$} & \multirow{2}{*}{ Flood Characteristic } & \multirow{2}{*}{$\begin{array}{c}\text { Aerial } \\
\text { photograph }\end{array}$} & \multicolumn{2}{|c|}{ Satellite imagery } \\
\hline & & & $\begin{array}{c}30 m \\
D E M\end{array}$ & $\begin{array}{c}12 m \\
D E M\end{array}$ \\
\hline \multirow{4}{*}{ 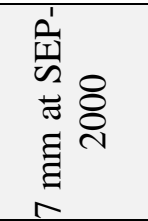 } & Volume of runoff $\times 1000 \mathrm{~m}^{3}$ & 10.55 & 14.72 & 13.85 \\
\hline & Peak runoff rate $\mathrm{m}^{3} / \mathrm{sec}$ & 0.41 & 0.49 & 0.44 \\
\hline & Depth of water $(\mathrm{mm})$ & 0.84 & 0.83 & 0.83 \\
\hline & Sediment yield (tones) & 53.33 & 58.24 & 40.36 \\
\hline \multirow{4}{*}{ 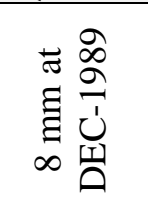 } & Volume of runoff $\times 1000 \mathrm{~m}^{3}$ & 15.67 & 21.88 & 20.59 \\
\hline & Peak runoff rate $\mathrm{m}^{3} / \mathrm{sec}$ & 0.7 & 0.81 & 0.7 \\
\hline & Depth of water $(\mathrm{mm})$ & 1.24 & 1.24 & 1.24 \\
\hline & Sediment yield (tones) & 90.68 & 97.63 & 67.11 \\
\hline \multirow{4}{*}{ 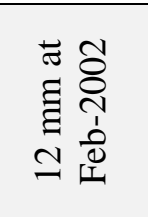 } & Volume of runoff $\times 1000 \mathrm{~m}^{3}$ & 42.42 & 59.24 & 55.73 \\
\hline & Peak runoff rate $\mathrm{m}^{3} / \mathrm{sec}$ & 2.37 & 2.64 & 2.24 \\
\hline & Depth of water $(\mathrm{mm})$ & 3.36 & 3.36 & 3.36 \\
\hline & Sediment yield (tones) & 320.64 & 339.17 & 231.02 \\
\hline \multirow{4}{*}{ 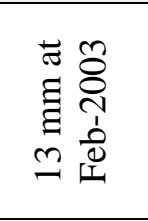 } & Volume of runoff $\times 1000 \mathrm{~m}^{3}$ & 50.29 & 70.24 & 66.07 \\
\hline & Peak runoff rate $\mathrm{m}^{3} / \mathrm{sec}$ & 2.89 & 3.21 & 2.71 \\
\hline & Depth of water $(\mathrm{mm})$ & 3.98 & 3.98 & 3.98 \\
\hline & Sediment yield (tones) & 394.35 & 416.97 & 283.82 \\
\hline \multirow{4}{*}{ 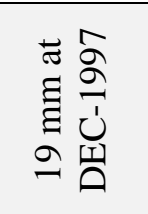 } & Volume of runoff $X 1000 \mathrm{~m}^{3}$ & 103.95 & 145.21 & 136.58 \\
\hline & Peak runoff rate $\mathrm{m}^{3} / \mathrm{sec}$ & 6.46 & 7.22 & 5.94 \\
\hline & Depth of water $(\mathrm{mm})$ & 8.23 & 8.23 & 8.23 \\
\hline & Sediment yield (tones) & 931.94 & 984.14 & 668.69 \\
\hline \multirow{4}{*}{ 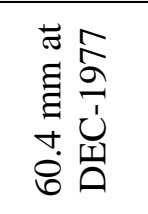 } & Volume of runoff $\times 1000 \mathrm{~m}^{3}$ & 573.88 & 801.91 & 754.15 \\
\hline & Peak runoff rate $\mathrm{m}^{3} / \mathrm{sec}$ & 37.29 & 41.86 & 33.72 \\
\hline & Depth of water $(\mathrm{mm})$ & 45.46 & 45.45 & 45.45 \\
\hline & Sediment yield (tones) & 6476.12 & 6833.11 & 4634.15 \\
\hline \multirow{4}{*}{ 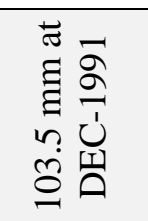 } & Volume of runoff $\times 1000 \mathrm{~m}^{3}$ & 1103.21 & 1541.67 & 1449.81 \\
\hline & Peak runoff rate $\mathrm{m}^{3} / \mathrm{sec}$ & 70.55 & 79.44 & 63.85 \\
\hline & Depth of water $(\mathrm{mm})$ & 87.38 & 87.37 & 87.38 \\
\hline & Sediment yield (tones) & 13340.41 & 14085.8 & 9551.7 \\
\hline
\end{tabular}

From Table (12) the volume of runoff and sediment yield is extracted and the difference (\%) from aerial photo computed as shown in Table (13 and 14) and plotted in Figure (17 and 18). 


\begin{tabular}{|l|l|}
\hline WR & 1 \\
\hline
\end{tabular}

Table (13) the difference (\%) of the volume runoff for rainfall events

\begin{tabular}{|c|c|c|c|c|c|}
\hline \multicolumn{6}{|c|}{ Volume of runoff $\times 1000 \mathrm{~m}^{3}$} \\
\hline \multirow[b]{2}{*}{ Rainfall event } & \multirow[b]{2}{*}{ Aerial photograph } & \multicolumn{2}{|c|}{ Satellite imagery } & \multicolumn{2}{|c|}{ Difference \% } \\
\hline & & $\begin{array}{c}\text { 30m } \\
\text { DEM }\end{array}$ & $\begin{array}{l}12 \mathrm{~m} \\
\text { DEM }\end{array}$ & For 30m DEM & For $12 m D E M$ \\
\hline $7 \mathrm{~mm}$ & 10.55 & 14.72 & 13.85 & 39.53 & 31.28 \\
\hline $8 \mathrm{~mm}$ & 15.67 & 21.88 & 20.59 & 39.63 & 31.40 \\
\hline $12 \mathrm{~mm}$ & 42.42 & 59.24 & 55.73 & 39.65 & 31.38 \\
\hline $13 \mathrm{~mm}$ & 50.29 & 70.24 & 66.07 & 39.67 & 31.38 \\
\hline $19 \mathrm{~mm}$ & 103.95 & 145.21 & 136.58 & 39.69 & 31.39 \\
\hline $60.4 \mathrm{~mm}$ & 573.88 & 801.91 & 754.15 & 39.73 & 31.41 \\
\hline $103.5 \mathrm{~mm}$ & 1103.21 & 1541.67 & 1449.81 & 39.74 & 31.42 \\
\hline
\end{tabular}

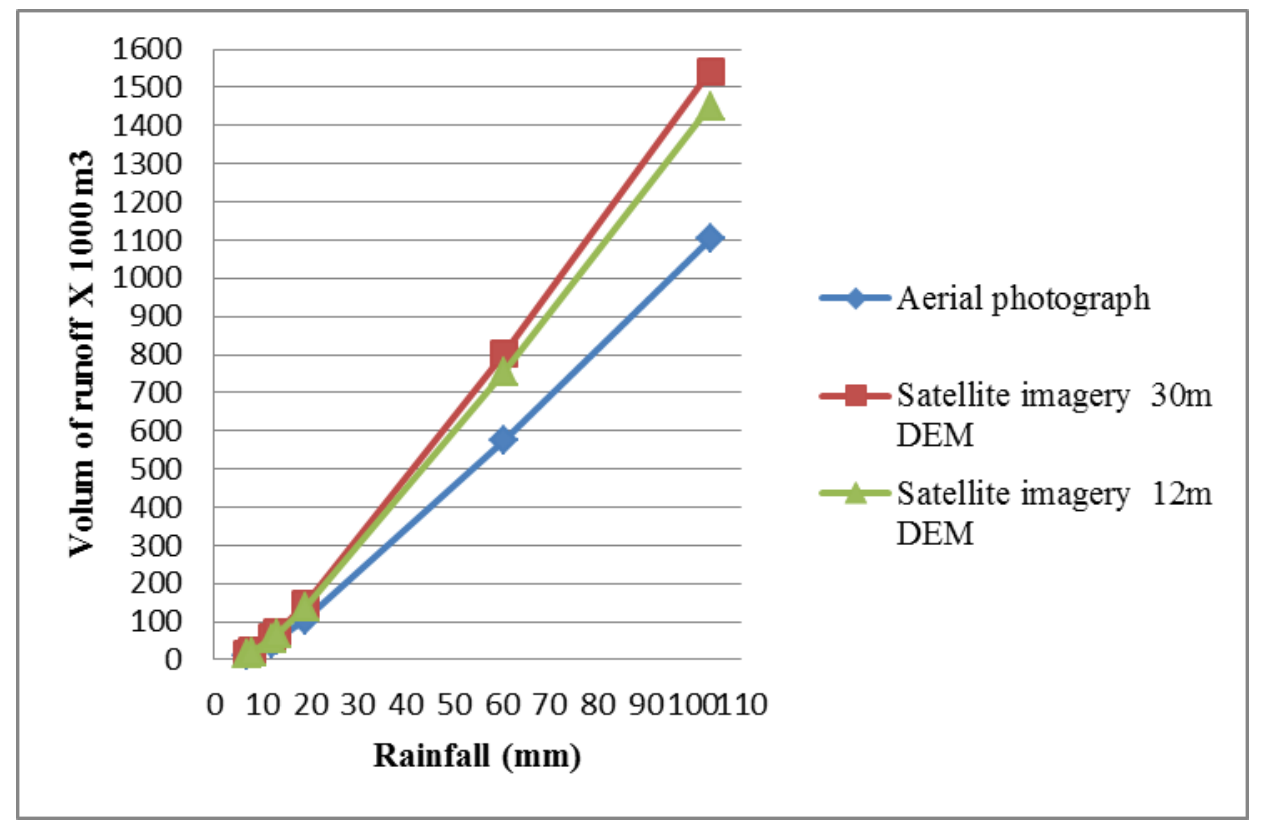

Figure (17) Volume of the runoff for different rainfall events 
Table (14) the difference (\%) of the sediment yield for rainfall events

\begin{tabular}{|c|c|c|c|c|c|}
\hline \multicolumn{7}{|c|}{ Sediment yield (tones) } \\
\hline \multirow{2}{*}{ Rainfall event } & \multirow{2}{*}{ Aerial photograph } & \multicolumn{2}{|c|}{ Satellite imagery } & \multicolumn{2}{c|}{ Difference \% } \\
\cline { 3 - 6 } & & $\begin{array}{c}\mathbf{3 0 m} \\
\text { DEM }\end{array}$ & $\begin{array}{c}\mathbf{1 2 m} \\
\text { DEM }\end{array}$ & For 30m DEM & For 12m DEM \\
\hline $7 \mathrm{~mm}$ & 53.33 & 58.24 & 40.36 & 9.21 & 24.32 \\
\hline $8 \mathrm{~mm}$ & 90.68 & 97.63 & 67.11 & 7.66 & 25.99 \\
\hline $12 \mathrm{~mm}$ & 320.64 & 339.17 & 231.02 & 5.78 & 27.95 \\
\hline $13 \mathrm{~mm}$ & 394.35 & 416.97 & 283.82 & 5.74 & 28.03 \\
\hline $19 \mathrm{~mm}$ & 931.94 & 984.14 & 668.69 & 5.60 & 28.25 \\
\hline $60.4 \mathrm{~mm}$ & 6476.12 & 6833.11 & 4634.15 & 5.51 & 28.44 \\
\hline $103.5 \mathrm{~mm}$ & 13340.41 & 14085.8 & 9551.7 & 5.59 & 28.40 \\
\hline
\end{tabular}

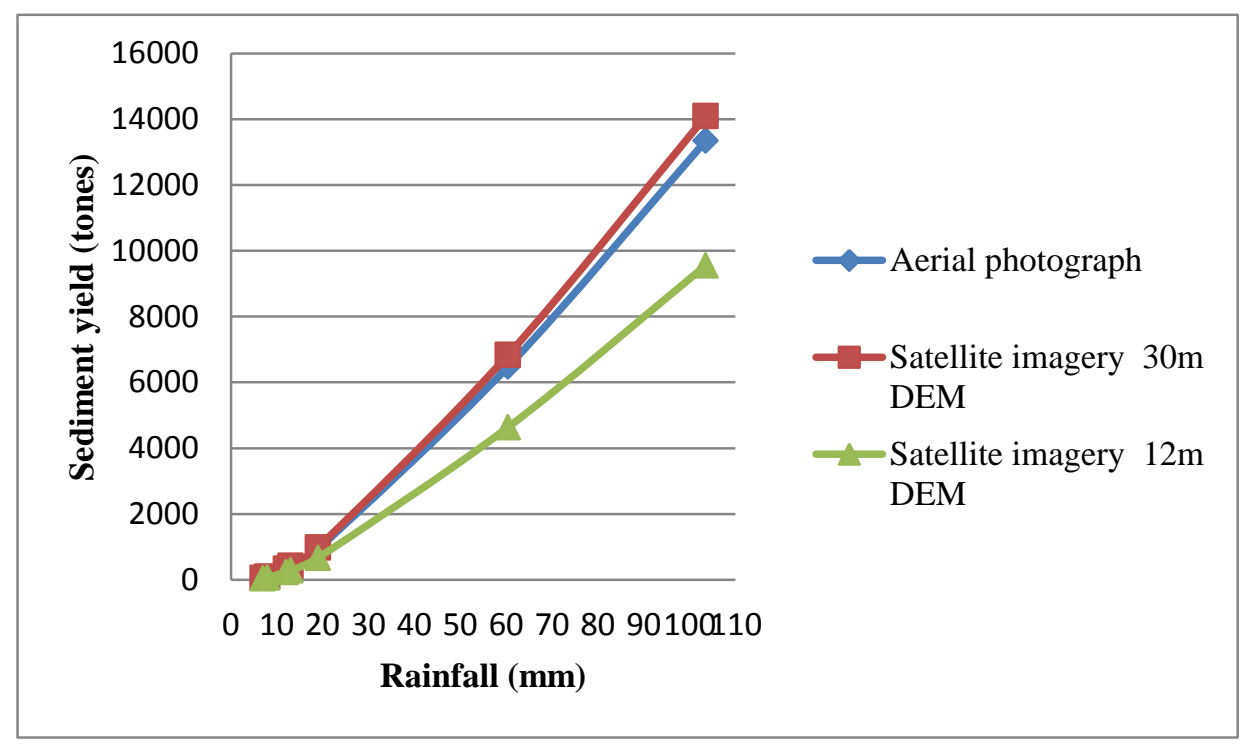

Figure (18) Sediment yield for different rainfall events 


\section{Conclusion and recommendations}

1- This study shows that the DEMs resolutions are effect in the watershed delineation.

2- The volume of runoff resulted from $12 \mathrm{~m}$ DEM resolution is closer to aerial photo than $30 \mathrm{~m}$ DEM in all rainfall events from $(7 \mathrm{~mm}$ to $103.5 \mathrm{~mm})$.

3- The volume of runoff for $12 \mathrm{~m}$ and $30 \mathrm{~m}$ DEM is differ than that aerial photo by approximately $31 \%$ and $39 \%$, respectively.

4- For the rainfall events less than 20mm, the DEMs resolutions dose not effect on the volume runoff.

5- The sediment yield resulted from 30m DEM is closer to aerial photp than $12 \mathrm{~m}$ DEM in all rainfall events.

6- The sediment yield for 30m DEM is differ than that of aerial photo by approximately $7 \%$ and $26 \%$ respectively.

It is recommended to use DEM to represent the surface ground immediately after the year of storm event to match the changes of drainage pattern for this storm, it is also recommended to insert the exact duration of the storm event in WASHMO model. 


\section{References}

1. Zhang, W. and D.R. Montgomery, Digital elevation model grid size, landscape representation, and hydrologic simulations. Water resources research, 1994. 30(4): p. 1019-1028.

2. Mamillapalli, S., et al. Effect of spatial variability on basin scale modeling. in Proceedings, Third International Conference/Workshop on Integrating GIS and Environmental Modeling, Santa Fe, New Mexico. 1996.

3. FitzHugh, T.W. and D. Mackay, Impacts of input parameter spatial aggregation on an agricultural nonpoint source pollution model. Journal of hydrology, 2000. 236(1): p. 35-53.

4. Chaplot, V., Impact of DEM mesh size and soil map scale on SWAT runoff, sediment, and NO 3-N loads predictions. Journal of hydrology, 2005. 312(1): p. 207-222.

5. El Shazly, M. and A. Shata, Geomorphology and pedology of Mersa Matrh area, Western Mediterranean Littoral Zone. Desert Institute Bulletin, 1971. 19: p. 1-28.

6. Shata, A., Geology and geomorphology of Wadi El Kharrupa area. Publ. inst. Desert, Egypt, 1957: p. 91-120.

7. Haan, C.T. and B.J. Barfield, Hydrology and sedimentology of surface mined lands. 1978.

8. Kent, K., A method for estimating volume and rate of runoff in small watersheds. 1973.

9. Ward, A., C. Haan, and J. Tapp, The DEPOSITS sedimentation pond design manual. Institute for Mining and Minerals Research, Office of informational Services and Technical Liaison, Univ. of Kentucky, Lexington, Ky, 1979.

10. Sutko, T.E. and S. Flippin. Design Storms and Sizing of Flood Control Facilities. in Hydraulics/Hydrology of Arid Lands (H²AL). 1990. ASCE.

11. Hershfield, D.M., Rainfall frequency atlas of the United States for durations from 30 minutes to 24 hours and return periods from 1 to 100 years. US Department Commerce Technical Paper, 1961. 40: p. 1-61.

12. Wischmeier, W.H. and D.D. Smith, Predicting rainfall erosion losses-a guide to conservation planning. Predicting rainfall erosion losses-a guide to conservation planning., 1978. 